\title{
Microtitre plate method for alanine transferase (ALT)
} assays

\author{
A C ARCHER, D F GREEN, E J BUCKLAND South West Regional Blood Transfusion \\ Centre, Southmead, Bristol
}

SUMMARY A kinetic assay for alanine transferase (ALT) using microtitre plates and commercially available reagents was developed to retain the advantages conferred by multichannel and semiautomated equipment. The time taken to assay 92 samples was less than 10 minutes, and costs of apparatus and reagents compared favourably with most current methods.i Although reactions became non-linear above $120 \mathrm{IU} / 1^{-1}$, higher concentrations were "flagged" and accuracy was satisfactory below this point.

Alanine transferase activity (ALT) has been used widely as a surrogate test for non-A, non-B hepatitis and may be introduced in the United Kingdom. To retain the advantages of multichannel and semiautomated equipment, a microtitre plate ALT screen was considered to be desirable.

This study used commercially available reagents, with adjustments to the volumes. A computer program was written to calculate the ALT activities of samples, following calibration with a set of standards. The results obtained with blood donor samples were compared with those of a previous study using two established commercial methods.

\section{Material and methods}

Assays using the Beckman series 700 and the Gemstar system were performed according to the manufacturer's instructions, using Beckman Dri-Stat and Gemstar reagents. Both assays couple the primary aminotransferase reaction to a dehydrogenase reaction, with concomitant oxidation of nicotinamide adenine dinucleotide (NADH). The rate of the resulting decrease in optical density at $340 \mathrm{~nm}$ is directly proportional to ALT activity.

For the microtitre method we used a Hamilton microlab "MT" to dispense $40 \mu \mathrm{l}$ aliquots of test serum into a U-well microtitre plate. Three standards (Beckman "Decision" 1, 2, and 3) were added and the plate was transferred to a Flow Laboratory "Twinreader 2" microtitre plate-reader. After allowing the plate to warm to $37^{\circ} \mathrm{C}$ the plate-reader program was started. This program dispensed $180 \mu \mathrm{l}$ of prewarmed Beckman "Dri-Stat" ALT reagent, then read the

Accepted for publication 3 March 1988 optical density at $340 \mathrm{~nm}$. Two further readings we:e taken at two minute intervals. All of the optical density readings were passed to a BBC "Master" microcomputer via the RS232/423 ports.

The microcomputer was programmed to calculate the average optical density change per unit of ALT from the value given by the standards. This constant was then used to calculate ALT activity for the test samples. The computer program also checked the linearity of reactions on all results, and checked for substrate exhaustion during the preincubation stage. A cut off of 2.25 standard deviations above the logarithmic mean was applied.

\section{Results}

A total of 2527 random blood donations were tested; 624 of these were tested within eight hours of collection, the remaining 1903 after storage at $4^{\circ} \mathrm{C}$ for up to 24 hours. The results were compared with those of 638 donors assayed with a Beckman Clinical System 700 and Gemstar (table 1). Repeat tests were necessary for $2.5 \%$ of the microtitre tests using stored samples, where non-linearity resulted from turbidity. Non-linear reactions with fresh sera were almost invariably due to very high activities of ALT. Similar problems were found when stored samples were used with the Beckman series 700 test.

Two standards supplied by Wellcome Reagents Ltd were used to measure the precision of the microtitre assay. The intra-assay coefficient of variation was found to be $4 \cdot 1 \%$ with Wellcomtrol B $01\left(41 \mathrm{IU} / 1^{-1}\right)$, and $2.0 \%$ with Wellcomtrol BC $50\left(112 \mathrm{IU} / 1^{-1}\right)$. The corresponding interassay figures were $5.4 \%$ (BC 01 ) and $3.7 \%$ (BC 50 ).

As both the "standard formula" and the "SCE" 
Table 1 Donor screening results

\begin{tabular}{|c|c|c|c|c|}
\hline Method & $\begin{array}{l}\text { Number } \\
\text { tested }\end{array}$ & $\begin{array}{l}\text { Mean } A L T \\
(I u / l)\end{array}$ & $\begin{array}{l}\text { Cut-off* } \\
(I u / l)\end{array}$ & $\begin{array}{l}\text { Donors } \\
\text { above } \\
\text { cut-off }\end{array}$ \\
\hline $\begin{array}{l}\text { Gemstar } \\
\text { Beckman series } 700 \\
\text { Microtitre }\end{array}$ & $\begin{array}{l}177 \\
451\end{array}$ & $\begin{array}{l}16 \cdot 5 \\
20 \cdot 7\end{array}$ & $\begin{array}{l}40 \cdot 5 \\
53 \cdot 1\end{array}$ & $\begin{array}{l}1 \cdot 7 \% \\
2 \cdot 3 \%\end{array}$ \\
\hline $\begin{array}{l}\text { (fresh samples } \\
\text { Microtitre }\end{array}$ & 624 & $21 \cdot 7$ & 53.9 & $2 \cdot 1 \%$ \\
\hline (stored samples) & 1903 & $21 \cdot 8$ & $53 \cdot 1$ & $2.4 \%$ \\
\hline
\end{tabular}

*2.25 standard deviations above log mean.

version of Dri-Stat reagents were being used, 74 samples were tested with both reagents and subjected to regression analysis (table 2). Regression analysis was also supplied to 10 samples assayed by the microtitre method and by the biochemistry laboratory, Frenchay Hospital, Bristol. These were samples found to be close to the cut off, and the correlation around this point appears to be satisfactory. A third regression analysis was applied to fresh and stored samples assayed with the Beckman 700 analyser.

Several samples with very high activities of ALT, supplied by the Biochemistry Laboratory, Southmead Hospital, Bristol, were tested on each run. These were all detected by the linearity or substrate exhaustion checks.

\section{Discussion}

The advisability of screening blood donors with surrogate tests remains a controversial issue. ${ }^{1-5}$ This study was concerned only with the means of ALT screening on such a large scale; although still at an early stage of development, the microtitre method allows 92 samples to be dispensed and assayed in less than 10 minutes.

ALT activities measured using different temperatures, reagents, or analysers show considerable variation. ${ }^{1}$ For this reason we used a cut off calculated at 2.25 standard deviations above the log mean, and standards to calibrate each microtitre plate. The interassay precision was found to be $5 \cdot 4 \%$ at $41 \mathrm{IU} / 1^{-1}$. This is equivalent to about $2 \cdot 2 \mathrm{IU} / \mathrm{l}^{-1}$, although the figure will be influenced to some extent by the means of dispensing serum samples.

The checks for linearity and substrate exhaustion proved essential for "flagging" ALT activities above $120 \mathrm{IU} / \mathrm{1}^{-1}$. This limit should not prove a problem as it
Table 2 Regression analysis of paired samples

\begin{tabular}{|c|c|c|c|c|}
\hline Methods compared & Number & Slope & Intercept & Correlation \\
\hline \multicolumn{5}{|l|}{$\begin{array}{l}\text { Microtitre method } \\
\text { "standard" } v \text { SCE ALT }\end{array}$} \\
\hline reagents & 74 & $1 \cdot 13$ & 1.22 & 0.992 \\
\hline \multirow{3}{*}{$\begin{array}{l}\text { Microtitre method } v \\
\text { pathology laboratory } \\
\text { Beckman series } 700 \\
\text { fresh } v \text { stored samples }\end{array}$} & 10 & 0.970 & 0.17 & 0.994 \\
\hline & & & & \\
\hline & 90 & $1 \cdot 128$ & -2.7 & 0.981 \\
\hline
\end{tabular}

is assumed that Transfusion Centres would retest samples wth ALT activities above the cut off.

Costs of reagents and apparatus should compare favourably with existing methods; the $180 \mu \mathrm{l}$ of substrate used is considerably less than most ALT assays, and standard U-well microtitre plates are inexpensive.

One technical problem remaining is the nonlinearity of results in some stored samples. As it affected both the microtitre and Beckman series 700 systems, it is assumed to be a general problem where samples are stored at $4^{\circ} \mathrm{C}$ overnight without separating the serum from the clot.

We thank Beckman-RIIC Ltd, Diagnostic Products (UK) Ltd, Ultro Labs, and Flow Laboratories for the supply of reagents and loan of machinery. We also thank John Kirkpatrick of the UK Transplant Service for help with statistics, and the director and staff of the South West Regional Transfusion Centre for their support.

\section{References}

1 Zuck TF, Sherwood WC, Bove JR. A review of recent events related to surrogate testing of blood to prevent non-A, non-B post-transfusion hepatitis. Transfusion 1987;27:203-6.

2 International Forum. Based on your analysis of the benefits and costs of routine donor screening for ALT-GPT to reduce the incidence of post-transfusion non-A, non-B hepatitis in your blood services region, what action would you recommend on this matter? Vox Sang 1983;44:48-64.

3 Anderson CC, Contreras M, Barbara JAJ, Mijovic V. Surrogate testing for non-A, non-B hepatitis. Lancet 1987;i:912.

4 Dow BC, Mitchell R, Follett EAC. Non-A, non-B hepatitis surrogate testing of blood donations. Lancet 1987; i:1366.

5 Gillon J, Hussey AJ, Howe SP, Beckett GJ, Prescott RJ. Non-A, non-B hepatitis surrogate testing of blood donations. Lancet 1987;:1366-7.

Requests for reprints to: Mr A C Archer, Regional Blood Transfusion Centre, Southmead, Bristol BS10 5ND, England. 